\title{
Effect of Wirand FS7-II Steel Wire Fibre on Flexural Capacity of Reinforced Concrete Beam
}

\author{
Amir Hossein Jodeiri* , Ronaldo J. Quitalig \\ School of Graduate Studies, Mapua Institute of Technology (MIT) Manila, 1550, Philippines
}

\begin{abstract}
Concrete is good in compression but today fibre reinforced concrete is perhaps one of the most realistic possibilities to develop the use of concrete in load bearing structures. The hooked-end steel fibre with the dimensions of 0.55 $\mathrm{mm}$ in diameter, $33 \mathrm{~mm}$ in length and with the aspect ratio of 60 were used in this study. It was concluded that the volume fraction of steel fibre FS7-II was $1 \%\left(23.77 \mathrm{~kg} / \mathrm{m}^{3}\right)$. In conventional concrete two beams are used whereas concrete beam with steel fibre FS7_II 1\% also had two model and model three removed from reinforced rebar at the top. The overall dimensions of the beams were $200 \mathrm{~mm}$ in height, $150 \mathrm{~mm}$ in width, and $940 \mathrm{~mm}$ in length. The beams were tested under third-point loading test for 28 days. The results showed that the addition of steel fibres in concrete increases the first cracking load, ultimate load, stiffness and ductility of the concrete beams. In comparison with the control concrete group's maximum increase in the compressive strength at $1 \%$ steel fibre was 12.37 at 7 days, $10.44 \%$ at 14 days and $5.58 \%$ at 28 days. Increase in the flexural strength at $1 \%$ steel fibre was $19.42 \%$ at 28 days for model two and $6.76 \%$ at 28 days for model three. In general, the significant improvement strength was observed with the inclusion of steel fibres in the conventional concrete with $1 \%$. In this study concrete beam to continued carry load after cracking had occurred, called post crack behaviour or toughness. The first crack load $\left(\mathrm{P}_{\mathrm{cr}}\right)$ was determined from the curve and SFRC beams showed significant increase in the first crack load over reinforced concrete beams. Th is increased the flexural modulus of rupture which showed that model two got $19.48 \%$ and model three got $6.7 \%$ if the beams were containing $1 \%$ steel fibres. The SFRC beams with $1 \%$ volu me fraction of fibres showed an average increase model two with $19.44 \%$ and model three with $6.76 \%$ in ultimate load $\left(\mathrm{P}_{\mathrm{u}}\right)$ when compared to RC beams.
\end{abstract}

Keywords Flexural Strength, Compressive Strength, Steel Fibre, Ultimate Load, First Cracking Load

\section{Introduction}

\subsection{Back Ground}

Steel fibres have been used in concrete since the early 1900s. The early fibres were rounded, smoothed and the wire was cut or chopped to the required lengths. The use of straight, smooth fibres had largely disappeared and modern fibres have either rough surfaces, hooked ends or are crimped or undulated through their length. The use of steel fibre has been well established as complementary reinforcement to improve certain properties of concrete elements. Fibre reinforcement has been shown to improve the ductility, toughness, flexu ral strength, and shear strength of cementations materials. As defined in this template, but do not change or redefine them in any way as this will lead to unpredictable results. You do not need to remember shortcut keys.

* Corresponding author:

ajodeiri@mymail.mapua.edu.ph (Amir Hossein Jodeiri)

Published online at http://journal.sapub.org/jce

Copyright (C 2012 Scientific \& Academic Publishing. All Rights Reserved
Steel fibre reinforced concrete should only be used in a supplementary role to inhibit cracking to improve resistance to impact or dynamic loading and to resist material disintegration. The study concluded that the beneficial effects of steel fibres decrease with increasing bar. Steel fibres uniformly distributed the volume of concrete and rebar much higher shear strength are close to each other. Steel fibres can also provide an adequate internal restraining mechanis m when shrinkage-co mpensating cements are used.

The use of steel fibre reinforced concrete beam for structural applications was hindered by the absence of a codified design approach. Therefore there was a need to establish and assess design models for various design aspects on the use of steel fibre reinforced in various structural applications. In order to improve the tensile strength stability and cracking properties in RC beams were used with steel fibres. Effects of steel fibres on flexural capacity performance, shrinkage and improved resistance cracking mechanical properties of RC beams were investigated in this study.

\subsection{Objective}




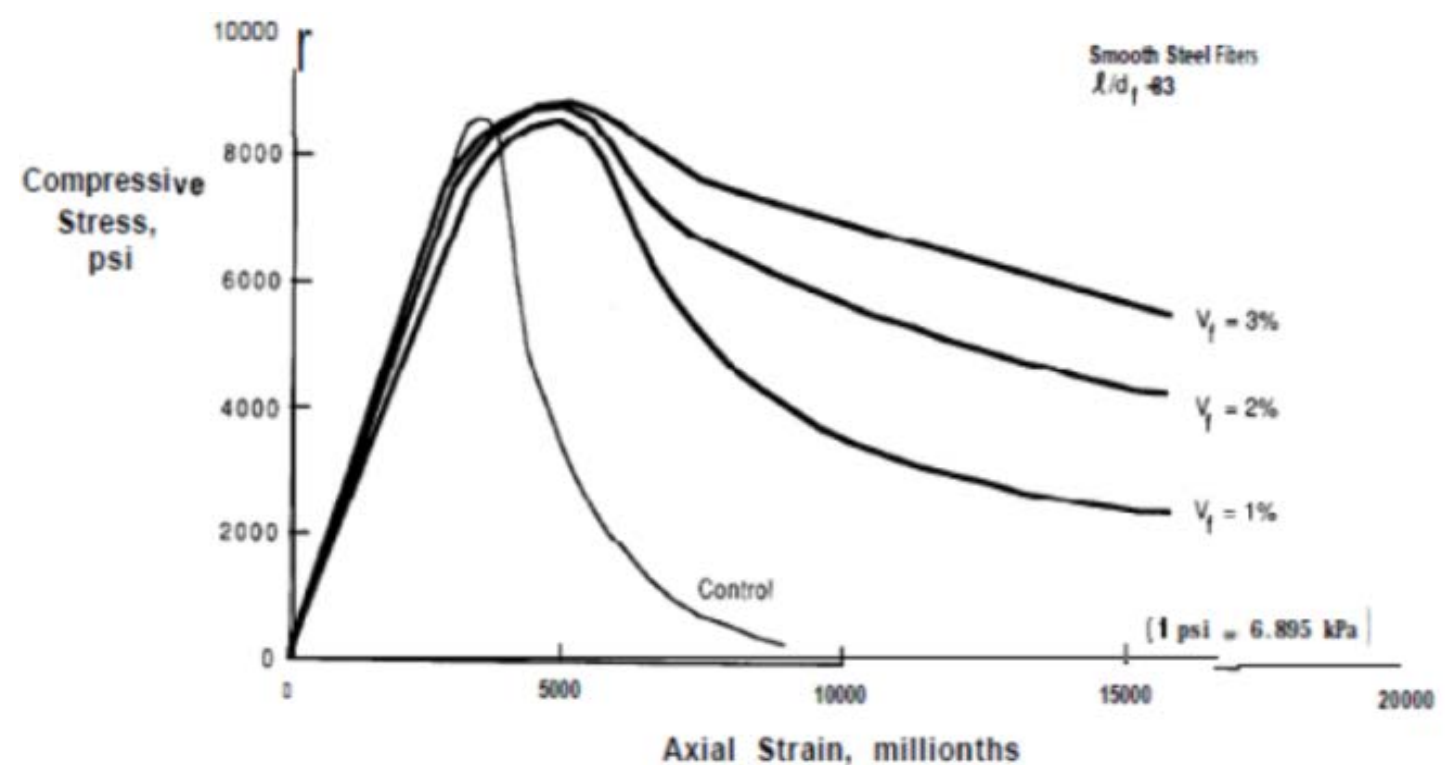

Figure 1. Influence of amount of steel fibres on the compressive stress behaviour

The main objective of this study is to determine the effect of Winrad FS7- II steel fibre on flexural capacity of reinforced concrete beams compared with the conventional reinforced concrete beams and concrete beams with bottom rebar. Flexural performance of steel fibre re inforced concrete (SFRC) beams with compressive strength of concrete. This investigation aims to obtain experimental data on the deformation characteristics and strength of reinforced concrete to determine the flexural behaviour of tensionfailure RC beams.

The most significant improvement imparted by adding fibres to a concrete mix was the substantial increase in the flexural capacity. Composite material which was named as steel fibre concrete has been applied in various applications extensively. In this study, steel fibre rein forced concrete was examined under flexure and its characteristics were determined.

\subsection{Review of Related Literature}

The compressive behaviour of concrete was influenced by properties of its constituent materials. Concrete with a low water-to-cement ratio may display high compressive strength. Normal concrete with high compressive strength usually shows more brittle behaviour. For small a mounts of steel fibres added to concrete, the compressive strength in concrete does not significantly improve .However, post-cracking ductility of the composite may be improved with the addition of steel fibres figure 1[1].

Fatih Altun et al, (2005) consider addition effects of two different dosage of hooked steel fibres (30 and $60 \mathrm{~kg} / \mathrm{m}^{3}$ ) on toughness strength of concrete. Steel fibres were added into two grades of concrete, 20 and 30 . The steel fibres used in their research were $60 \mathrm{~mm}$ in length and $0.75 \mathrm{~mm}$ in diameter with tensile strength of $1050 \mathrm{~N} / \mathrm{mm}^{2}$. Their results showed that energy absorption of 2 capacities (toughness) of concrete grade 20 and 30 increased by $121 \%$ and $135 \%$ with addition of steel fibre dosages of $30 \mathrm{~kg} / \mathrm{m} 3$ and 60 $\mathrm{kg} / \mathrm{m} \wedge 3[2]$.

Research of Darwish et al, showed that an addition of up to $1.5 \%$ of fibres by volume increases the compressive strength from 0 to $15 \%$. A gradual slope in the descending portion of the fibre reinforcement concrete (FRC) stress-strain curve indicates improved spelling resistance, ductility and toughness as shown in Figure2[3].

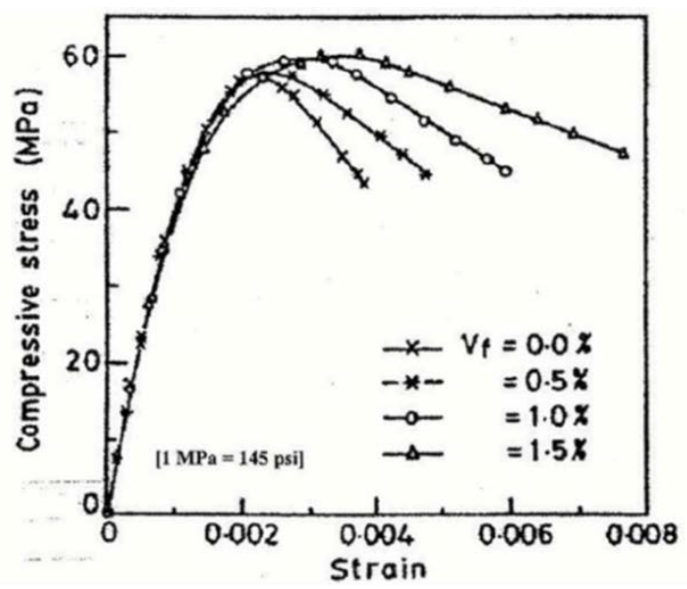

Figure 2. Effects of Steel Fibres Content on Compressive Stress-Strain Curve of FRC (Padmarajaiah and Ramaswamy, 2002)

The influence of steel fibres on the flexural strength of concrete is much greater than for direct tension and compression .The flexural strength of fibre reinforcement concrete increased by about $55 \%$ with a $V_{f}=2 \%$ as reported[4].

\section{Methodology}

The observation in this research was concentrated on determining the flexural capacity of RC beams with the addition of $1 \%$ steel fibre FS7- II was $23.77 \mathrm{~kg} / \mathrm{m}^{3}$ in 
concrete. Furthermore, the research wanted to study how well the steel fibres would improve the flexural capacity of the concrete beams with the conventional steel bar reinforcement. In this study, steel fibre reinforced concrete (SFRC) was a composite material made of hydraulic cements, water, fine and coarse aggregate and a dispersion of discontinuous, small fibres. All admixtures meeting ASTM specifications for use in concrete are suitable for use in steel fibre rein forced concrete SFRC which was shown in Table1.

Table 1. Specification of Steel Fibers which Used in This Study

\begin{tabular}{|c|c|c|c|c|c|}
\hline $\begin{array}{c}\text { Diameter(D) } \\
(\mathrm{mm})\end{array}$ & $\begin{array}{c}\text { Length } \\
(\mathrm{L})(\mathrm{mm})\end{array}$ & $\mathrm{D} / \mathrm{L}$ & $\begin{array}{c}\text { Speci fic } \\
\text { Gravity } \\
\left(\mathrm{Kg} / \mathrm{m}^{3}\right)\end{array}$ & $\begin{array}{c}\text { Tensile } \\
\text { Strength } \\
(\mathrm{MPa})\end{array}$ & $\begin{array}{c}\text { Strain at } \\
\text { Failure }\end{array}$ \\
\hline 0.55 & 33 & 60 & 7850 & 800 & $2 \%$ \\
\hline
\end{tabular}

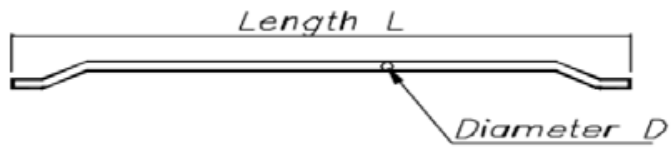

Figure 3. Steel Fibre Winrad @FS7_II Used in This Study

In this study the required data for the use in analytical model was obtained through experimental testing. Two phases of experiments were conducted: experiments for preliminary conventional concrete reinforced behaviour and experiments for verification of analytical models Steel fibre reinforced concrete beam (SFRC). In this study an indirect tensile test method was used to determine the ultimate (maximum) tensile strength rebar used in this study. A compressive test was conducted to determine the compressive responded of SFRC, establishing the ultimate compressive strength yield compressive strain was used in cylinder of concrete. In this study two samples for conventional concrete cylinder was used and two samples was used for concrete cylinder with $1 \%$ steel fibre.

This study included three models; model one conventional concrete beam two samples, model two concrete beam with steel fibre two samples and model three concrete beam without top steel reinforced but with steel fibre two samp le in 28 days. The overall dimensions of the beam are $200 \mathrm{~mm}$ thickness, $150 \mathrm{~mm}$ width and $940 \mathrm{~mm}$ lower support as shown in Figure 4. The size of main reinforcement used in the concrete beam was $12 \mathrm{~mm}$ in diameter and the link reinforcement was made of hot rolled mild steel with $6 \mathrm{~mm}$ in diameter arranged at $100 \mathrm{~mm}$ centre to centre. In this study utilized three model of beams, with steel fibre and without steel fibre.
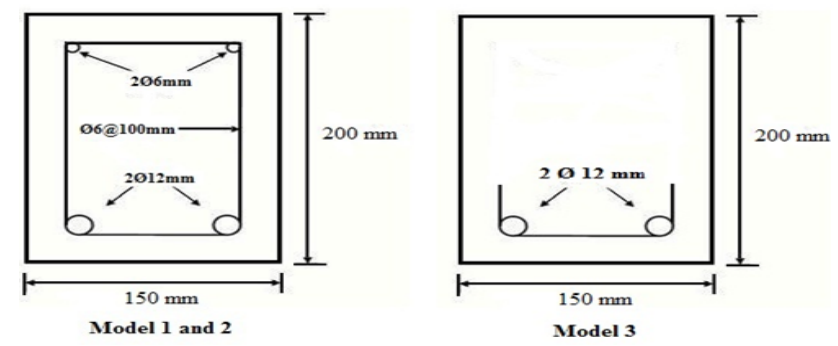

Figure 4. Gross Section of RC Beams
Rebar testing was a basic tensile test where an escalating tensile load was applied to a rebar specimen until it y ields or breaks revealing important data about the specimen's strength. This load frame features a top-mounted hydraulic actuator which was place in the loading area at ground level. This significantly reduced our lifting requirements for loading the heavy rebar specimens. The strength of main reinforcement $12 \mathrm{~mm}$ in diameter $\mathrm{f}_{\mathrm{y}}$ was $502.33 \mathrm{~N} / \mathrm{mm}^{2}$ and strength of $6 \mathrm{~mm}$ in diameter $\mathrm{f}_{\mathrm{y}}$ was $427.18 \mathrm{~N} / \mathrm{mm}^{2}$. In this study for the tensile strength test (I) 2 rebar was used to reinforce $12 \mathrm{~mm}$ and $6 \mathrm{~mm}$ and length for testing $500 \mathrm{~mm}$. the elongation of rebar $12 \mathrm{~mm}$ in diameter was $100 \mathrm{~mm}$ while rebar $6 \mathrm{~mm}$ in diameter was $50 \mathrm{~mm}$.

Materials used for the concrete includes Ordinary Portland cement; the cement was keep on an airtight container and stored in the humidity controlled room to prevent cement from being exposed to moisture, fine aggregate (sand) and coarse aggregate; The sand was use natural river sand and the coarse aggregate was $3 / 8^{\prime \prime}$ crushed granite. Water; Water was needed for the hydration of cement and to provide workability during mixing and placing. The study, normal tap water was used. Steel fibres; the steel fibre used in this study was hooked end shape. The specification mix proportioning of the concrete used in the study was shown in Table 2.

Table 2. Mix Proportioning of the Concrete

\begin{tabular}{|c|c|}
\hline Ingre dients & Weight $\mathbf{( k g / \mathbf { m } ^ { 3 } )}$ \\
\hline W/C Ratio & 0.40 \\
\hline Mix Water(lit) & 225 \\
\hline Cement(Portland) & 600 \\
\hline Fine Agg.(Sand) & 816 \\
\hline Coarse Agg. (3/8’) & 736 \\
\hline Total batch weight & $\mathbf{2 3 7 7}$ \\
\hline Steel Fibre FS7_II (1\%) & 23.77 \\
\hline
\end{tabular}

The pouring of concrete was carried in a laboratory with a temperature $27^{\circ} \mathrm{C}$.

Third -point loading test was conducted until the beams reached failure. Data to be collected includes: ultimate strength of the beams at failure, load - deflection characteristics of the beams, location and shape of cracks occur on the beams and mode of structural failure of the concrete beams [5].

The study was used ASTM C1609 / C1609M, standard test method for flexural performance of fibre reinforced concrete (Using Beam with Third-Point Loading). Th is test method evaluates the flexural performance of fibre reinforced concrete using parameters derived from the load deflection curve obtained by testing a simply supported beam under third-point loading using a closed-loop servo-controlled testing system. It also requires determination of residual loads at specified deflections, the corresponding residual strengths calculated by inserting them in the formu la for modulus of rupture given in Equation (1) [6]. 


$$
\mathrm{f}=\mathrm{PL} / \mathrm{bd}^{2}
$$

Where: $\mathrm{f}=$ the strength, MPa (psi), $\mathrm{P}=$ the load, $\mathrm{N}$ (lbf), $\mathrm{L}=$ the span length, $\mathrm{mm}$ (in), $\mathrm{b}=$ the average width of the specimen at the fracture, as oriented for testing, $\mathrm{mm}$ (in), $\mathrm{d}=$ the average depth of the specimen at the fracture, as oriented for testing, mm (in).

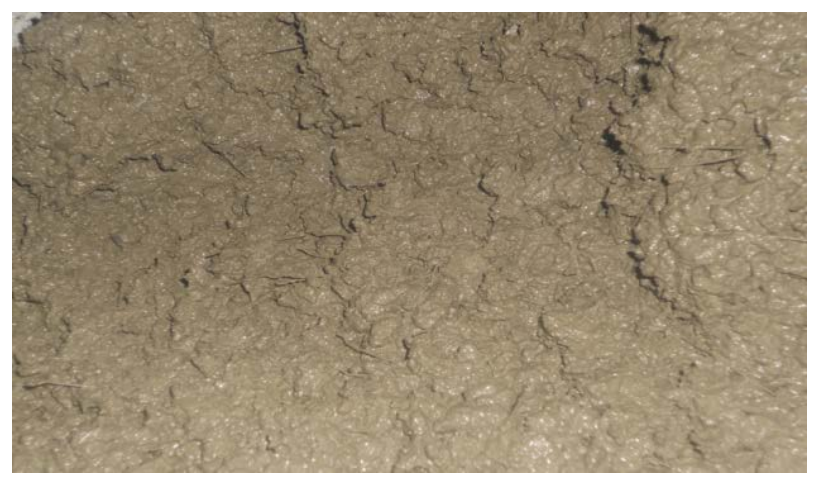

Figure 5. Concrete with $1 \%$ Steel Fiber FS7 _II

\section{Results and Discussion}

The results of compressive strength test of concrete cylinder with $1 \%$ steel fibre FS7_II $\left(23.77 \mathrm{~kg} / \mathrm{m}^{3}\right)$ and conventional concrete cylinder at 7, 14 and 28 days were shown in Table 3.

Table 3. Compressive Strength of Normal and St eel Fibre Added Concrete cylinder

\begin{tabular}{|c|c|c|c|}
\hline sample & $\begin{array}{c}\text { Strength } \\
7 \text { day (MPa) }\end{array}$ & $\begin{array}{c}\text { Strength } \\
14 \text { day } \\
\text { (MPa) }\end{array}$ & $\begin{array}{c}\text { Strength } \\
\text { 28 day } \\
\text { (MPa) }\end{array}$ \\
\hline $\begin{array}{c}\text { Conventional } \\
\text { cylinder }\end{array}$ & 40.15 & 43.71 & 46.68 \\
\hline Mean & & 44.73 & 47.50 \\
\hline $\begin{array}{c}\text { STANDARD } \\
\text { DEVIATIO N } \\
\text { OFTHE } \\
\text { MEAN }\end{array}$ & & 44.22 & 47.09 \\
\hline C $\%$ & 0.72 & 0.57 \\
\hline $\begin{array}{c}\text { Concrete } \\
\text { cylinder with } \\
\text { 1\% steel fibre }\end{array}$ & 45.15 & 48.79 & 48.53 \\
\hline Mean & & 48.89 & 50.92 \\
\hline $\begin{array}{c}\text { STANDARD } \\
\text { DEVIATIO N } \\
\text { OF THE } \\
\text { MEAN }\end{array}$ & & 48.84 & 49.72 \\
\hline C $\%$ & 0.070 & 1.68 \\
\hline C $_{\mathrm{v} \text { Allowable }}$ & & 0.144 & 3.39 \\
\hline
\end{tabular}

It can be seen that the addition of $1 \% \mathrm{~V}_{\mathrm{f}}$ steel fibres had the most increase in compressive strength. This enhancement in uniaxial strength was due to the internal passive confinement of the matrix by steel fibres which also delays the crack spreading and propagation. In comparis on with control concrete, the maximum increased in the compressive strength with $1 \%$ steel fibre was $12.37 \%$ at 7 days, $10.44 \%$ at 14 days and $5.58 \%$ at 28 days.

The addition of steel fibre to volume fraction of $1 \%$ caused an increase in compressive strength of concrete at early ages. In general, the increase in compressive strength of high performance steel fibre concrete was attributed to the capability of steel fibre to delay the unstable development of micro-cracks as well as to limit the propagation of these micro-cracks and the composite was affected for concrete and steel fibres under load. However, there must be merit in including fibres to provide increased ductility in a compressive failure[7].

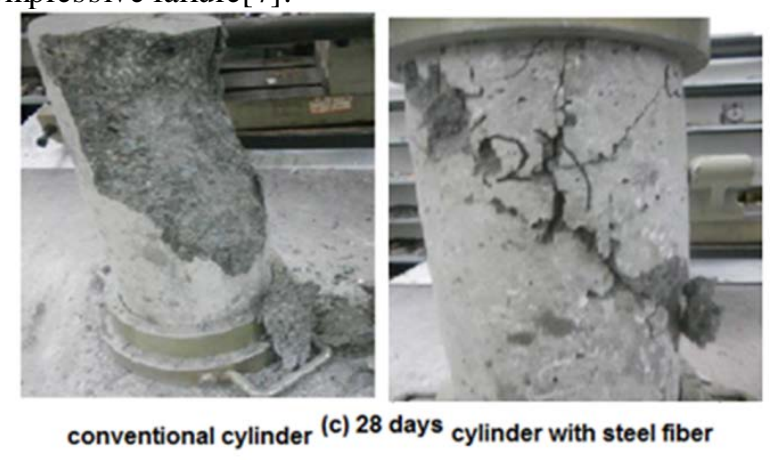

Figure 6. Failure of cylinder in compressive test at 28th

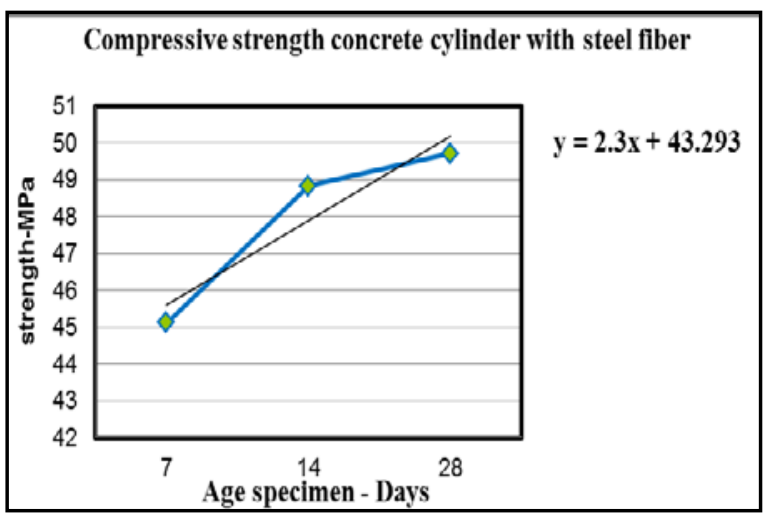

(a) Linear Regression of Sample Concrete Cylinder with 1\% Steel Fiber FS7-II

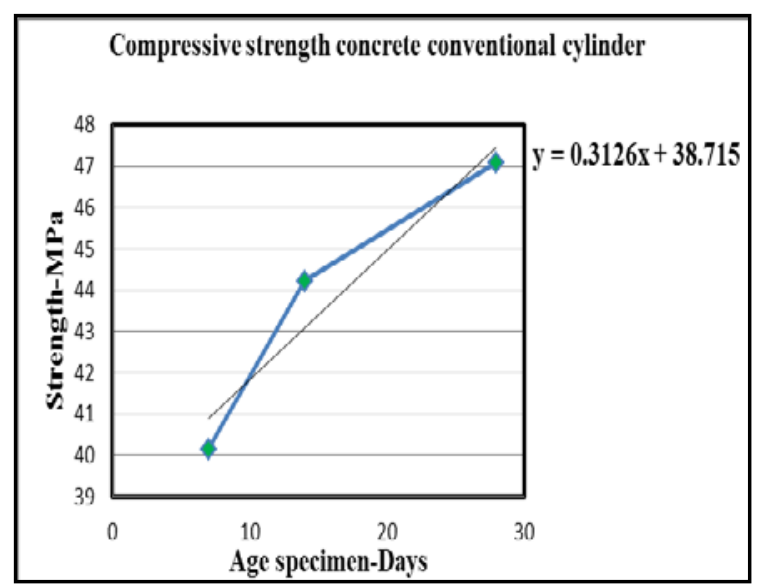

(b) Linear Regression Conventional Concrete Cylinder

Figure 7. Linear Regression

The experimental investigation also observed two type of failure for the cylindrical specimen. During the splitting strength test for conventional concrete, the cylindrical specimens were completely split but for steel fibre there was only a single crack line that occurred on the cross- section 
from the top loading plate. The crack line also continued the length of the cylindrical specimen. The specimen with steel fibre had greater than forced. It had elastic behaviour in compressive test as well as to limited propagation of micro cracks and the composite effect for concrete and steel fibres under load. However, there may be merit in including fibres to provide increased ductility in a compressive failure [8].

The study evaluated the coefficient of variation and linear regression. There was a significant relationship between the variables in the linear regression model of the data set faithful as presented in Figure 7(a), (b).

The flexural group standard - cured specimens were also evaluated according to the degree of relat ionship between the time and the strength. The flexural test result of these specimens is presented in table 4. Basically, the behaviour under flexural is the most important aspect ratio for steel fibre, because the practical application is subjected to some kind of bending load. The flexural strength trend on all samples with $1 \%$ steel fibres increased[9].

Table 4. Flexural Strength of Normal and Steel Fibre 1\% Added Concrete Beam

\begin{tabular}{|c|c|}
\hline \multirow{2}{*}{ sample } & $\begin{array}{c}\text { Flexural Strength } \\
\text { 28 day (MPa) }\end{array}$ \\
\hline \multirow{2}{*}{ Model 1 } & 15.73 \\
\cline { 2 - 2 } Mean & 16.78 \\
\hline $\begin{array}{c}\text { STANDARD DEVIATION } \\
\text { OF THE MEAN }\end{array}$ & 16.255 \\
\hline \multirow{2}{*}{ Model 2 } & 0.742 \\
\hline \multirow{2}{*}{ Mean } & 18.73 \\
\cline { 2 - 2 } & 20.11 \\
\hline \multirow{2}{*}{$\begin{array}{c}\text { STANDARD DEVIATIO N } \\
\text { OF THE MEAN }\end{array}$} & 19.42 \\
\hline \multirow{2}{*}{ Model 3 } & 0.975 \\
\hline Mean & 16.67 \\
\hline & 17.355 \\
\hline ST ANDARD DEVIATION & 15.73 \\
\hline
\end{tabular}

In comparison with controlled concrete, the maximum increased in the flexural strength with $1 \%$ steel fibre was $19.42 \%$ for model two at 28 days and $6.76 \%$ for model three at 28 days. Furthermore compressions model two and model three increased the flexural strength $11.89 \%$ at 28 days. In general, the significant imp rovement in various strengths was observed with the inclusion of $1 \%$ steel fibres in the conventional concrete. However it can be shown that there was an increase for model three because this model removed the reinforced rebar at the top.

The behaviour of cracks propagated on the conventional beam groups under bending showed comparability in figure 8 and 9 the crack started from the extreme flexure substrate and gradually inclined to finally approach the near point loading. The cracking patterns in all beams were almost symmetrical and characterized by the load induced that created the flexural - shear cracks visible enough. Since the initial cracks on the concrete beams model two specimens were not visible until such time as the maximum load reached the increase in the propagation of the cracks was visible enough[10].

For the concrete beam with steel fibre $1 \%$ model two fine vertical flexural cracks were formed first, usually the bottom face of the beam close to mid span. The width of these initial cracks was very small. In fact, the steel fibres can sustain the stress after cracking at strain beyond the normal for the failure of conventional concrete beam. Some sort of stress distribution was promoted which approached the full plastic condition in the tension zone, while remaining elastic in the compression zone. This mechanis m caused the neutral axis of the section to move up, thus the moment of resistance and ultimate load was increased significantly[11].

This behaviour was mainly attributed to the role of steel fibre in releasing fracture energy around crack tips which was required to extent crack growing by transferring stress from one side to another side. Also this behaviour was due to the increase in crack resistance of the composite and the ability of fibres to resist forces after the concrete matrix had cracked[11].
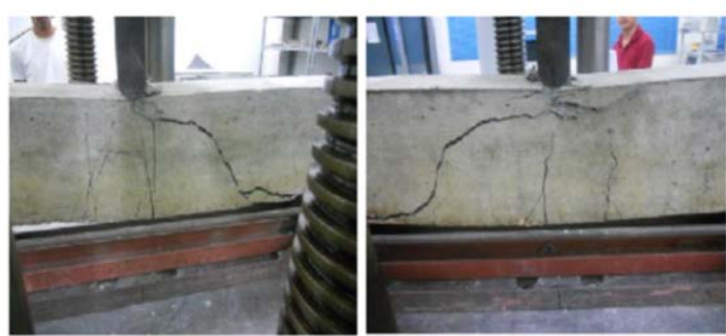

Conventional Beam tested to destruction 28th day specimen

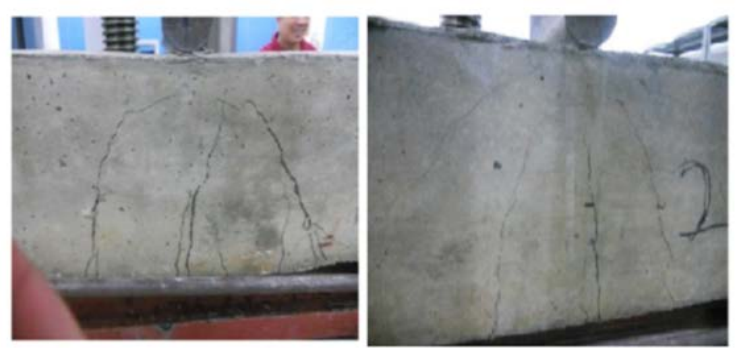

Concrete Beam with steel fiber Model 2 tested to destruction 28th day specimen Figure 8. Schemat ic of Typical Fracture Patterns under Bending
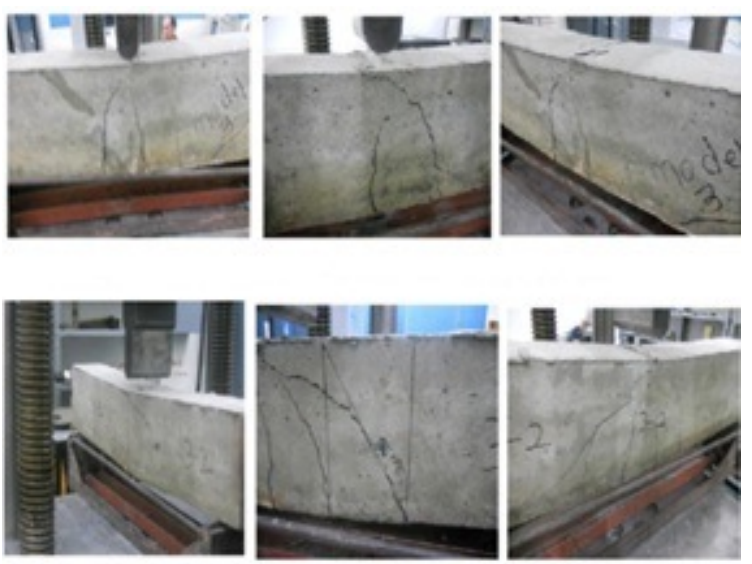

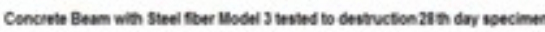

Figure 9. Schematic of Typical Fracture Pattems under Bending 
The micromechanical advantage for adding steel fibre in conventional concrete can be seen by its post cracking effects, ductility and energy absorption. The steel fibres when uniformly dispersed throughout the specimens act as reinforcement and help for better distribution of stresses. Therefore, the cracks that occurred in steel fibre concrete beam specimens were smaller in size compared with the conventional concrete and even more did break up at ultimate load. Alternatively, the toughness may be defined as the area under the load-deflection curve out to some particular deflection or out to the point at which the load had fallen back to some fixed percentage of the peak load[12].

Table 5 was showed the summary of the independent ttest for the determining significant difference of the strength between the conventional beam and concrete beam with $1 \%$ steel fibre at 28 days of flexural strength.

$$
\mathrm{t}=(\overline{\mathrm{X}}-\mu) /(\mathrm{S} / \sqrt{\mathrm{N}})
$$

Where: $\mathrm{X}$ is the respective means of the sample. $\mathrm{S}$ is the respective standard deviation of the sample. $\mathrm{N}$ is the respective number of sample. The degrees of freedom used in this test was $(n 1+n 2)-2$.

Table 5. Compression of t-test Flexural Strength at 28 day

\begin{tabular}{|c|c|c|}
\hline $\mathbf{H}_{0}$ & \multicolumn{2}{|c|}{$\mu_{1}=\boldsymbol{\mu}_{\mathbf{2}}$} \\
\hline $\mathrm{H}_{1}$ & \multicolumn{2}{|c|}{$\mu_{1}>\mu_{2}$} \\
\hline $\mathbf{n}$ & \multicolumn{2}{|c|}{2} \\
\hline df & \multicolumn{2}{|c|}{$\left(n_{1}+n_{2}\right)-2=2$} \\
\hline$\alpha$ & \multicolumn{2}{|c|}{$\alpha=0.05$} \\
\hline NAME & $\mathbf{S}$ & 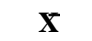 \\
\hline $\begin{array}{c}\text { Conven tional Concrete } \\
\text { Beam } \\
\text { Model 1 } \\
\end{array}$ & 0.742 & 16.255 \\
\hline $\begin{array}{c}\text { Concre te Beam With 1\% } \\
\text { Steel Fibre Fs7_II } \\
\text { Model } 2\end{array}$ & 0.975 & 19.42 \\
\hline$t_{\text {actual }}$ & \multicolumn{2}{|c|}{3.65} \\
\hline$t_{\text {critial }}$ & \multicolumn{2}{|c|}{2.92} \\
\hline
\end{tabular}

The result showed that the mean difference on the strength reached 3.65 with standard deviation of 0.74 and 0.97 respectively fro $m$ the conventional beams strengths and concrete beam with $1 \%$ steel fiber strengths. When the mean difference was tested for significance a computed actual $t$ value of 3.65 was generated. It was relatively higher than the critical $t$ value of 2.92 to the idea that the difference was significant. The enormous increase $1 \%$ steel fiber was an affirmation that the present study effect of W inrad FS7- II steel fiber on flexural capacity of reinforced concrete beam was effective at the 0.05 level of significance under flexural.

The first crack load (Pcr in Table 6) was determined from the curve. All the SFRC beams showed significant increase in the first crack load over re inforced concrete beams. It also required determination of residual loads at specified deflections, the corresponding residual strengths calculated by inserting them in the formula Equation (1). The first-peak strength characterizes the flexural behaviour of the fibre-reinforced concrete up to the onset of cracking, while residual strengths at specified deflections characterize the residual capacity after cracking.

Table 6. Comparison the Flexural Strength and First orack, Model 1, Model2, Model3

\begin{tabular}{|c|c|c|c|c|}
\hline Specimen & $\begin{array}{c}\text { Flexural } \\
\text { strengh } \\
\text { MPa }\end{array}$ & $\begin{array}{c}\text { First } \\
\text { crack } \\
\text { KN }\end{array}$ & $\begin{array}{c}\text { Peak } \\
\text { load } \\
\text { KN }\end{array}$ & $\begin{array}{c}\text { Deflection } \\
\mathrm{mm}\end{array}$ \\
\hline $\begin{array}{c}\text { Conventional } \\
\text { Concrete } \\
\text { Beam Model 1 }\end{array}$ & 10.48 & 55 & 66.92 & 9.33 \\
\hline MEAN & 11.18 & 52 & 71.42 & 26.89 \\
\hline $\begin{array}{c}\text { Concrete } \\
\text { Beam with }\end{array}$ & 12.48 & 55 & 79.68 & 14.21 \\
$\begin{array}{c}\text { Steel fiber 1\% } \\
\text { Model 2 }\end{array}$ & 13.40 & 62 & 85.56 & 11.91 \\
\hline MEAN & 12.94 & 58.5 & 82.62 & 13.06 \\
\hline $\begin{array}{c}\text { Concrete } \\
\text { Beam with }\end{array}$ & 11.11 & 66 & 76.78 & 7.05 \\
$\begin{array}{c}\text { Steel fiber 1\% } \\
\text { Model 3 }\end{array}$ & 12.02 & 54 & 70.92 & 24.64 \\
\hline MEAN & 11.56 & 60 & 73.85 & 15.84 \\
\hline
\end{tabular}

The increase in the flexural modulus of rupture was about model two with $19.48 \%$ and model three with $6.7 \%$ in case beams containing $1 \%$ steel fibres. The SFRC beams with $1 \%$ volume fraction of fibres, showed an average increase of model two with $19.44 \%$ and model three $6.76 \%$ in ultimate load (Pu) when compared to RC beams. Hence, it can be said that the addition of steel fibres caused the increase of both ultimate load and first crack load. This increase can be due to the crack arresting mechanis m of the closely spaced fibres.

In other cases, fibres may significantly increase the first-peak and peak strengths while affecting a relatively small increase in residual load capacity and specimen toughness at specified deflections. The first-peak strength, peak strength and residual strength determined by this test method reflect the behaviour of fibre reinforced concrete under static flexural loading. First peak deflection for third point loading was estimated assuming linear elastic behaviour up to first peak from equation (3):

$\delta=23 \mathrm{PL}^{3} / 1296 \mathrm{EI}^{*}\left\{1+\left[\left(216 \mathrm{D}^{2} *(1+\mu)\right) / 115 \mathrm{~L}^{2}\right]\right\} \quad$ Eq. (3) Where $\mathrm{P}$ is the first-crack load, $\mathrm{L}$ is the span, $\mathrm{E}$ is the estimated modulus of elasticity of the concrete, $\mathrm{I}$ is the cross-sectional moment of inertia, D is the specimen depth, and $\mu$ is Poisson's ratio.

Table 7. First peak load, Net deflection at First peak load

\begin{tabular}{|c|c|c|c|c|c|}
\hline \multirow{2}{*}{ At 28 day } & $\begin{array}{c}\text { First peak } \\
\text { load } \\
\text { KN }\end{array}$ & $\begin{array}{c}\text { peak load } \\
\text { KN }\end{array}$ & $\begin{array}{c}\boldsymbol{\delta}_{1} \\
\mathbf{m m}\end{array}$ & $\begin{array}{c}\boldsymbol{\delta}_{\mathbf{~}} \\
\mathbf{m m}\end{array}$ & $\begin{array}{c}\boldsymbol{\delta} \\
\mathbf{L} / 600 \\
\mathbf{m m}\end{array}$ \\
\hline MODEL 1 & 52 & 66.92 & 0.24 & $\mathbf{0 . 3 1}$ & 1.485 \\
\cline { 2 - 6 } & 57 & 71.49 & 0.27 & 0.34 & 1.32 \\
\hline \multirow{2}{*}{ MODEL 2 } & 55 & 79.68 & 0.26 & 0.37 & 1.595 \\
\cline { 2 - 6 } & 62 & 85.56 & 0.29 & 0.40 & 1.43 \\
\hline
\end{tabular}


Table 8. Residual load at net deflection

\begin{tabular}{|c|c|}
\hline At 28 day & $\mathbf{P}_{600}^{\mathbf{D}_{60}} \mathbf{N}$ \\
\hline \multirow{2}{*}{ MO DEL 1 } & 311877.3566 \\
\cline { 2 - 2 } & 277224.3169 \\
\hline \multirow{2}{*}{ MO DEL 2 } & 334979.383 \\
\cline { 2 - 2 } & 300326.3433 \\
\hline
\end{tabular}

The first peak strength characterizes the flexural behaviour of the fibre-rein forced concrete up to the onset of cracking while residual strengths at specified deflections characterize the residual capacity after cracking.

The area under the load deflection graph showed the ductility of the beams. It can be seen that the area under the beams containing steel fibres was more than the beams with conventional concrete. So, SFRC beams had more ductile behaviour than normal concrete beams [13].

It can be seen in Table 6 that although the addition of $1 \%$ steel fibres increased the ultimate load the deflection at ultimate load was less than conventional concrete beams. Hence, it can be said that the SFRC beams were stiffer than conventional concrete beams. The reason can be due to the effects of steel fibres and good bonding between steel fibres with the surrounding concrete which was act as confinement to the concrete.

When the specimens were loaded in bending setup, the maximum tension stress occurs at the bottom and the first crack develops. In the case without fibre, crack develops at near the centre and suddenly collapse. On the other hand, ductility was enhanced with the addition of fibres. Specimens with fibre never collapse suddenly and steel fib re holds crack parts together which was good for making reliable building[14].

High Performance steel fibre concrete exhibited increasing flexural strength with increasing in steel fibres compared with conventional concrete. This behaviour was mainly attributed to the role of steel fibre in releasing fracture energy around crack tips which was required to extent crack growing by transferring stress from one side to another side. Also this behaviour was due to the increase in crack resistance of the composite and the ability of fibres to resist forces after the concrete matrix has cracked. As recommended by ACI Committee 544, 'when used in structural applications, steel fibre reinforced concrete should only be used in a supplementary role to inhib it cracking to improved resistance impact or dynamic loading and to resist material disintegration[15].

Addition of steel fibres in the concrete mix significantly influenced the cracking behaviour and ultimate strength of beams. On the other hand, inclined cracks went through a slow process of widening and extension in beams of model two and model three with $1 \%$ of fibre content and without web reinforcement. In the study the main reason for incorporating steel fibres in concrete was to impart ductility to an otherwise brittle material. They enable concrete to continue to carry load after cracking has occurred, the so called post crack behaviour or toughness [16].

\section{Conclusions}

The aim of this study was to provide determination effect of Winrad FS7- II steel fibre on flexural capacity of reinforced concrete beams compared with conventional reinforced concrete beams and concrete beams with bottom rebar. It was anchored to the based information that greater volume of steel fibre has to conventional concrete. Generally, this study showed that the addition of 1\% steel fibre FS7_II improved the mechanical properties of concrete and RC beams.

Based on the finding of this study, the following conclusions were drawn: addition of steel fibres increases flexu ral and compressive strength of concrete. In co mparis on with control concrete the maximum increase in the compressive strength with $1 \%$ steel fibre was $12.37 \%$ at 7 days, $10.44 \%$ at 14 days and $5.58 \%$ at 28 days. The increase in compressive strength of high performance steel fibre concrete was attributed to the capability of steel fibre to delay the unstable development of micro cracks as well as to limitation the propagation of these micro cracks and the composite effect for concrete and steel fibres under load. Increase in the flexural strength with $1 \%$ steel fibre was $19.42 \%$ at 28 days for model two and $6.76 \%$ at 28 days for model three. In general, the significant improvement in various strengths was observed with the inclusion $1 \%$ of steel fibres in the conventional concrete. However it can be showed increase for model three because the model removed the reinforced rebar at the top. The initial cracks on the concrete beams model two specimens were not visible until such time the maximum load was reached, the increase in the propagation of the cracks was visible enough. Addition of steel fibres in the concrete mix significantly influenced the cracking behaviour and ultimate strength of beams. In the study the main reason for incorporating steel fibres in concrete was to impart ductility to an otherwise brittle material. They enable concrete to continue carry load after cracking had occurred called post crack behaviour, or toughness. The most remarkable changes in increasing strength by the used of short fibres to concrete occurs in bending. These changes included the increasing of flexural strength in pre-cracking stage and ductility of the concrete in post-cracking stage. It showed that the increasing amount of short fibres increase the load bearing capacity of the concrete. The first crack load $P_{c r}$ in Table 6 was determined from the curve. All the SFRC beams showed significant increase in first crack load over reinforced concrete beams. This increase flexural modulus of rupture was model two with $19.48 \%$ and model three with $6.7 \%$ in case beams containing $1 \%$ steel fibres. The SFRC beams with $1 \%$ volume fraction of fibres, showed an average increase of model two with $19.44 \%$ and model three with $6.76 \%$ in ultimate load $\left(\mathrm{P}_{\mathrm{u}}\right)$ when compared to RC beams. (8) The addition of $1 \%$ steel fibres increased the ultimate load but the deflection at ultimate load was less than the conventional concrete beams. Hence, it can be said that the SFRC beams were stiffer than conventional concrete beams. The reason can be due to the 
effects of steel fibres and good bonding between steel fibres with the surrounding concrete which was act as confinement to the concrete and also energy absorption under flexural loading which was greatly enhanced with steel fibre reinforcement.

\section{ACKNOWLEDGEMENTS}

I would like to express my sincere gratitude to my advisor Engineer Ronaldo J. Quailing, for his continuous support of my study and research, for his patience, motivation, enthusiasm and immense knowledge. He has given me guidance and advice on a personal and professional level that has been instrumental in my growth as an engineering student preparing to be a professional structural engineer.

\section{REFERENCES}

[1] ACI Committee 544.4R (1988) (Reapproved 2002). Design considerations for steel fiber reinforced concrete. ACI Structural Journal, volume 85(5), 563-580.New York.

[2] Fatih.A, Tefaruk. H., Kamura. A. (2005). Effects of steel fiber addition on mechanical properties of concrete and RC beams. Construction and Building Materials Volume 21 (21), 654-661.

[3] Darwish et al, (2008). Influence of fiber ratio in the size effect, Proceedings. International conference Concrete. Constructions sustainable option, Dundee.UK, PP 123-130.J. Padhye, V. Firoiu, D. Towsley, "A stochastic model of TCP Reno congestion avoidance and control", Univ. of Massachusetts, Tech. Rep. 99-02, 1999.

[4] 0. Olariu, I., A. Ioani, N. Poeinar (1988). Steel Fiber Reinforced Ductile Joints. Ninth World Conference on Earthquake Engineering, Tokyo-Kyoto, Japan, Aug.1988, 657-662.

[5] ASTM, C 78 -08 (2009). Standard Test Method for Flexural Strength of Concrete (Using Simple Beam with Third-Point Loading). A STM International, PP. 41, West Conshohocken, USA.

[6] ASTM, C 1609/C1609M (2009). Standard Test Method for Flexural Performance of Fiber-Reinforced Concrete (Using Beam with Third-Point Loading). ASTM International, PP. 837, West Conshohocken, USA.demic Publishing, Journal of Civil Engineering Research, vol.1, no.1, pp.1-8, 2011.

[7] Barros, J.A.O., Figueiras, J. (1999). Flexural behavior of steel fiber reinforced concrete, testing and modeling. Journal of
Materials in Civil Engineering, Volume 11(4), 331-39.Online Available: http://journal.sapub.org/ajb.

[8] Ezeldin, A., Balagurur, P. (1992). Normal-high strength fiber reinforced concrete under Compression. Journal of Materials in Civil Engineering, Volume 4(4), 415-29.

[9] F.B.A. Beshara, et al, (2009). Nominal Flexural Strength of High Strength Fiber Reinforced Concrete Beams. The 11th Arab Structural Engineering Conference, October 2009 KFUPM, Dhahran, Saudi Arabia.

[10] Ibrahim I.S., Che Baka, M.B. Procedia (2011). Effects on mechanical properties of industrialized steel fibers addition to normal weight concrete. International Journal of Recent Trends in Engineering, Volume 1, (2616), 130-145.

[11] Lakshmipathy, M., A. Santhakumar (1986). Experimental Verification of the Behavior of reinforced Fibrous Concrete Frames Subjected to Seismic Type 72 of Loading. Third International Symposium on Developments in Fiber Reinforced Cement and Concrete, Rilem, July (1986).

[12] Nasir. B. (2009). Steel Fiber Reinforced Concrete Made with Fibers Extracted from Used Tyers. M.S. Thesis submitted to the Schools of Graduate Studies. Addis Ababa University.

[13] Padmarajaiah, S.K., Ramaswamy, A. (2002). Finite Element Assessment of Flexural Strength of Fiber Reinforced High Strength Concrete Prestressed Beams. Journal of Cement and Concrete Composites, Volume 24, (2), 229-241.

[14] Rocco, C., Guinea, G., Planas, J. \& Elices, M.,( 2001). Review of the splitting-test standards from a fracture mechanics point of view. Cement and Concrete Research, Volume 31, 73-82.

[15] Soranakom, C., Mobasher, B. (2009). Flexural Design of Fiber-Reinforced Concrete. ACI Materials Journal, Volume 106(5), 870-75.

[16] Soranakom, C., Mobasher, B. (2007). Closed-form solutions for flexural response of fiber reinforced concrete beams. Journal for Engineering and Mechanics, Volume 133(8), 933-41.

[17] Vandewalle, L. et al. (2002). Recommendations of Rilem TC162-TDF: Test and Design Methods for Steel Fiber Reinforced Concrete Bending test final recommendation. Materials and Structures, Volume 35(2), 579-82.

[18] Tan, K.H., Paramasivam, P., Tan, K., (1995). Cracking characteristics of reinforced steel fiber concrete beams under short- and long - term loadings. Journal of the American Concrete Institute, Volume 65(3), 592-606.

[19] Wiliamson. G.R (1978). Steel Fibers as Reinforcement in Reinforced Concrete Proceeding, US Army Science Conference, West Point, Volume.3, 363-377. 